\title{
Review
}

\section{Hannah Arendt and the fragility of human dignity}

\author{
John Douglas Macready \\ Lanham, Lexington Books, 2018, xvi + 134pp., ISBN 978-1-4985-5490-9
}

Contemporary Political Theory (2019) 18, S37-S41. https://doi.org/10.1057/s41296018-0260-1; published online 3 September 2018

In a contemporary political context of widespread forced displacement and resurgent nativism in the West, scholars have become increasingly interested in Hannah Arendt's notion of 'the right to have rights.' Arendt developed this notion in response to the increase of stateless people in the interwar period and the failure of human rights during the Holocaust. She argues that, since human rights evidently cannot be assumed to protect the most vulnerable people, we must first recognize an underlying right to belong to a political community ahead of the specific rights that such a community might then provide. In recent years, scholars have debated whether this 'right to have rights' is a universal normative ground for rights, or, rather, a political claim that exists only insofar as it is asserted and recognized.

In his new book, John Douglas Macready engages with these debates through an examination of Arendt's closely related concept of 'human dignity.' Like the right to have rights, Arendt understands dignity as an attribute that somehow precedes or justifies human rights, and she claims in the aftermath of the Holocaust that, 'Human dignity needs a new guarantee' (Arendt, 1951, p. ix). Macready offers a reconstructive reading of Arendt's published works, letters, lectures, and journals in order to explicate her 'latent' model of dignity, compare this to traditional models, and determine if and how it supports human rights (p. 50).

To summarize Macready's argument, Arendt understands the dignity of human beings to be based upon their 'natality': that is, their 'capacity to initiate spontaneous and indeterminate action,' or, more broadly, 'the ability to think, speak, and act' (pp. 113-114). He claims, furthermore, 'These capabilities are universally shared by all human beings who have not suffered some diminishment of their capacities' (p. 114). Although the capacity for natality is universal, it is not an ahistorical human essence. Rather, it is 'an existential potency' that may or may not be actualized by a given individual (p. 111). Moreover, it is only when an individual is understood to have this potentiality that they have dignity. This means that human dignity must be asserted and recognized by particular people in order to

(C) 2018 Springer Nature Limited. 1470-8914 Contemporary Political Theory Vol. 18, S1, S37-S41 
exist: it is conditional, intersubjective, and political. Macready does argue that dignity provides a justification for human rights, but this is a fragile justification that can only be guaranteed insofar as we continually take up our political responsibilities. This account of Arendtian dignity is generally clear and convincing. However, to determine the upshot of the book for current debates, the relationship between dignity and existing readings of the right to have rights needs to be clarified.

In Chapter One, Macready argues that, throughout the 1950s, Arendt engaged in a critical reading of Karl Marx that shaped her understanding of conditionality, and a critical reading of Martin Heidegger that influenced her conception of natality. Macready draws on Arendt's Denktagebuch (intellectual diary) to show that she agrees with Marx's general claim that historical circumstances condition (bedingen) human existence. However, she questions his claim that these circumstances determine (bestimmen) human existence, because this seems to leave no room for human agency. Insisting that human action also conditions the world, Arendt 'took up Marx's uni-directional notion of conditionality and transformed it into bidirectional conditionality' (p. 15). Applied to the concept of dignity, this means that dignity can only be realized when appropriate historical conditions are in place, and also when individuals act to guarantee it. Furthermore, Arendt considers Marx's primary emphasis on economic conditions and the labor process to be incompatible with this bi-directionality, as she understands labor to be a realm of necessity, at odds with the freedom of human action. This attempt to divorce political action (and thus human dignity) from labor engenders Arendt's notoriously problematic critique of 'the social.' Yet Macready does not critically assess Arendt's attitude towards the social or her dubiously determinist reading of Marx.

Macready's account of the influence of Heidegger on Arendt's thought during this period is more satisfying. Arendt values Heidegger's critique of metaphysics and specifically his concept of Ereignis (the event of appropriation). However, whereas Heidegger conceived Ereignis in a way that alienates Dasein from others, Arendt reconceives appropriating events as expressions of 'natality': individuated actions made possible by an intersubjective world.

Macready acknowledges that Arendt did not undertake a sustained survey or explication of the concept of dignity but claims, in Chapter Two, that her explorations of other key political concepts yield a 'method' for rethinking concepts that can be used to disclose her latent model of dignity. According to this inferred model, dignity depends upon taking a 'stance' towards individuals that recognizes their capacity for natality. This contrasts with traditional accounts of dignity, which assert either the intrinsic superiority of human beings in general (stature), or the merit of individual human beings (status). Dignity as stance (like stature) is based on a natal capacity that all undiminished humans share; but (like status), it also must be asserted and intersubjectively recognized in individuals. Chapter Three further elaborates the worldly character of Arendtian dignity by 
unpacking seven key characteristics of the concept, including its connection to natality.

In Chapter Four, Macready seeks to show that Arendtian dignity supports human rights and provides a 'sufficient philosophical justification' or 'the formal conditions' for 'the right to have rights' (p. 92). When we recognize an individual as having dignity, we recognize them as a 'person,' 'a moral being - capable of self-determination and therefore responsible' (p. 95). This is necessary in order then to recognize their moral rights, to construct them as a legal person with legal rights and duties, and, ultimately, to bestow upon them full citizenship. For Arendt, the person is 'an intermediary figure,' 'who stands between the bare life of the human (zoē)' at one extreme, and 'the rights-bearing citizen (bios politikos)' at the other. It is 'the medium for the assertion of human dignity and the right to have rights' (p. 92). In extreme circumstances, such as the Nazi death camps, moral personhood can be entirely destroyed along with citizenship, leaving only bare physiological existence. Despite this fragility, depoliticized subjects such as the stateless can assert their moral personhood, and thus their dignity and right to have rights, in the absence of robust legal protections or citizenship. Macready claims that various critics of Arendt neglect to realize that she allows for subjects to assert their moral personhood in this way (p. 91). Ultimately, Macready argues, human dignity can be guaranteed as a basis for rights only when we face up to what Arendt called our 'predicament of common responsibility' (p. 115).

I am convinced by Macready's claim that Arendt understood dignity to be based on natality yet conditional on intersubjective recognition. In distinguishing dignity as a stance from traditional models of dignity as stature or status, he provides some framing of Arendt's view in relation to philosophical traditions. The further claim that Arendt understood dignity to imply moral personhood and to underwrite legal rights and citizenship is also convincing. Macready's use of Arendt's Denktagebuch and other unfamiliar materials is intriguing.

What I would have liked to hear more about from Macready is how his reading of Arendtian dignity relates to existing readings of her notion of the right to have rights. He states that his account of dignity 'attempts to navigate' the current debate between foundationalist interpreters of the right to have rights such as Seyla Benhabib and Peg Birmingham, and political interpreters such as Jacques Rancière and Ayten Gündoğdu (p. 35). Despite Macready's philosophical tendency to look for 'sufficient justifications' and 'formal conditions,' his account of dignity seems more closely to parallel political readings of the right to have rights, being similarly conditional on the assertion and recognition of people in the world. Nevertheless, a more detailed examination of this literature would be welcome in order to situate Macready's argument clearly within it. The ambiguity of Macready's position towards other critics is particularly puzzling when he conflates the contrasting views of foundationalist and political interpreters, claiming that both Benhabib and 
Rancière critique Arendt for failing to provide 'a universal norm guaranteeing rights' (p. 91).

Moreover, this begs the question of how, or if, the concept of dignity differs from the notion of the right to have rights. Although Macready claims that dignity provides the philosophical justification or formal conditions for the right to have rights, it is not clear from his argument why the former is the more fundamental concept. Both dignity and the right to have rights are based on the human capacity for natality, both require political recognition, both take the moral person as their medium, and both support human rights (see also Fig. 4.1, p. 97). In the Introduction, Macready asserts that 'many of Arendt's interpreters and critics have focused on Arendt's enigmatic concept of the "right to have rights" as a conceptual surrogate for human dignity, but few have focused exclusively on human dignity as it occurs in her work' (p. 4; emphasis added). But he does not explain why the right to have rights should be considered a mere 'surrogate.'

It may be that there is no real distinction between the roles played by dignity and the right to have rights in Arendt's thought; but because dignity is a key term in Arendt's lexicon, clarifying the resemblance between these two concepts is perhaps useful in itself. Indeed, Macready claims repeatedly that dignity is 'central' to Arendt's thought, and even that she was on 'a quest' for a model of dignity (pp. 3, 110 , ch. 1). Yet, if human dignity is such an abiding concern for Arendt, it is perplexing that she never discusses it in a sustained way.

Another possibility is that, although dignity and the right to have rights are one and the same, dignity is more commonly used in other theoretical and political discourses and so can bring Arendt's view of human rights into conversation with a broader audience. In that case, closer examination of the philosophical literature on dignity would be beneficial. Macready's references to the use of the term 'dignity' in political documents such as the UN Declaration of Human Rights and Germany's Grundgesetz are also suggestive but deserve more development.

Yet another possible reading is that dignity is a more capacious concept than the right to have rights. This approach could complicate or broaden Arendtian accounts of political obligation. One problem with the right to have rights is that it tends to obscure gradations of deprivation, distinguishing only between full citizens and those who are entirely rightless. This is a problem even for commentators such as Gündoğdu, who recognize the intermediary figure of the person as a potential bearer of rights distinct from the citizen (p. 104; Borren, 2017). Dignity is perhaps easier to understand as something that is denied to various degrees at various levels of political membership. The concept of dignity may also engage with aspects of human deprivation outside a framework of rights. The subjection of women, racial minorities, and workers is often not a result of the denial of formal rights. If the concept of dignity were used to contest socio-economic forms of deprivation, it could perhaps even provide an imminent critique of Arendt's most problematic views on the social question. 
A more detailed exploration of the concrete politics of asserting and recognizing dignity might have enabled Macready to elucidate these potential contributions of his argument to current debates. Nevertheless, the book opens doors onto central questions regarding human rights and Hannah Arendt's thought, and deserves to be read by anyone interested in these areas.

\section{References}

Arendt, H. (1951). The Origins of Totalitarianism. San Deigo, CA: Harcrourt Brace and Company. Borren, M. (2017). Rightlessness in an age of rights: Hannah Arendt and the contemporary struggles of migrants. Contemporary Political Theory 16(2): 269-273.

Lucy Cane

Beloit College, Beloit, WI 53511, USA canel@beloit.edu 